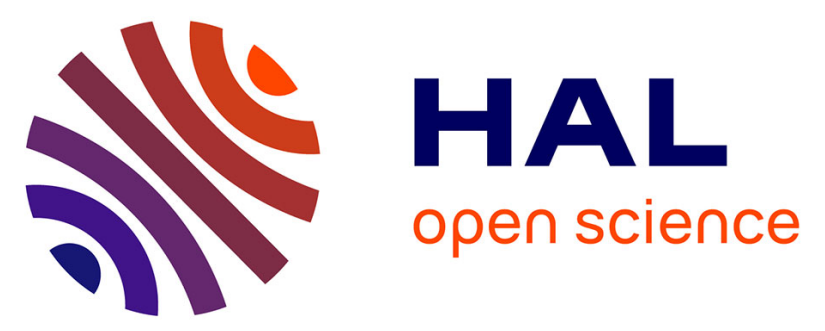

\title{
Individual vulnerability factors of Silver fir (Abies alba Mill.) to parasitism by two contrasting biotic agents: mistletoe (Viscum album L. ssp. abietis) and bark beetles (Coleoptera: Curculionidae: Scolytinae) during a decline process
}

Marion Durand-Gillmann, Maxime Cailleret, Thomas Boivin, Louis-Michel Nageleisen, Hendrik Davi

\section{- To cite this version:}

Marion Durand-Gillmann, Maxime Cailleret, Thomas Boivin, Louis-Michel Nageleisen, Hendrik Davi. Individual vulnerability factors of Silver fir (Abies alba Mill.) to parasitism by two contrasting biotic agents: mistletoe (Viscum album L. ssp. abietis) and bark beetles (Coleoptera: Curculionidae: Scolytinae) during a decline process. Annals of Forest Science, 2014, 71 (6), pp.659-673. 10.1007/s13595012-0251-y . hal-01102700

\author{
HAL Id: hal-01102700 \\ https://hal.science/hal-01102700
}

Submitted on 13 Jan 2015

HAL is a multi-disciplinary open access archive for the deposit and dissemination of scientific research documents, whether they are published or not. The documents may come from teaching and research institutions in France or abroad, or from public or private research centers.

$$
\text { Copyright }
$$

L'archive ouverte pluridisciplinaire $\mathbf{H A L}$, est destinée au dépôt et à la diffusion de documents scientifiques de niveau recherche, publiés ou non, émanant des établissements d'enseignement et de recherche français ou étrangers, des laboratoires publics ou privés. 


\title{
Individual vulnerability factors of Silver fir (Abies alba Mill.) to parasitism by two contrasting biotic agents: mistletoe (Viscum album L. ssp. abietis) and bark beetles (Coleoptera: Curculionidae: Scolytinae) during a decline process
}

\author{
Marion Durand-Gillmann • Maxime Cailleret • \\ Thomas Boivin • Louis-Michel Nageleisen • \\ Hendrik Davi
}

Received: 2 March 2012 / Accepted: 6 November 2012 /Published online: 22 November 2012

(C) INRA and Springer-Verlag France 2012

\begin{abstract}
- Context In recent decades, there have been increasing reports of forest decline, especially in Mediterranean forest ecosystems. Decline in tree vitality is usually due to complex interactions between abiotic factors and biotic agents that attack weakened trees.

- Aims and methods Estimating dendrometrical characteristics [basal area increment (BAI), age at DBH from tree ring counting, social status, height, and diameter], tree health status, and a competition index, we investigated the individual vulnerability of a French declining silver fir forest to both mistletoe (Viscum album L. ssp. abietis) and bark beetles (Pityophthorus pityographus Ratz., Pityokteines vorontzovi Jac., and Pityokteines spinidens Reitt.).
\end{abstract}

\footnotetext{
Handling Editor: Nathalie Breda

Contribution of the co-authors Marion Durand-Gillmann wrote the paper, designed the experiment in concert with Hendrik Davi, and ran the data analysis in concert with Hendrik Davi, Maxime Cailleret, and Thomas Boivin.

Louis-Michel Nageleisen and Thomas Boivin brought additional knowledge in entomology, especially on bark beetles.

Hendrik Davi supervised the work and coordinated the research project. This paper was proofread several times by Marion Durand-Gillmann and the co-authors.
}

M. Durand-Gillmann $\cdot$ M. Cailleret $\cdot$ T. Boivin $\cdot$ H. Davi $(\bowtie)$ INRA, UR629, Écologie des Forêts Méditerranéennes, Domaine Saint Paul Site Agroparc, 84194 Avignon CS40509 Cedex 9, France e-mail: hendrik.davi@avignon.inra.fr

\section{L.-M. Nageleisen}

Ministère de l'alimentation, de l'agriculture, de la pêche, de la ruralité et de l'aménagement du territoire DGAL/SDQPV, Département de la Santé des Forêts Antenne Spécialisée, Centre INRA de Nancy, 54280 Champenoux, France

\begin{abstract}
- Results BAI was negatively correlated with both mistletoe infection (via mistletoe biomass) and bark beetle attack (number of insects per square meter), but there was evidence of divergence in tree choice between two groups of parasites. Mistletoe preferentially infected isolated and dominant trees that showed higher past growth rates than non-infected ones. Conversely, bark beetles mainly attacked defoliated and preferably declining trees with diameter (DBH) lower than $44.5 \mathrm{~cm}$ and slower past growth.

- Conclusion While successive severe drought periods are thought to greatly weaken southern silver fir populations, mistletoe and bark beetles may contribute actively to their decline processes as inciting and contributing factors, respectively.
\end{abstract}

Keywords Viscum album L. · Bark beetles · Fir plantations · Parasitism · Growth

\section{Introduction}

As a transition zone between arid and humid regions of the world, the Mediterranean basin is generally considered particularly sensitive to climate change (Scarascia-Mugnozza et al. 2000). Mediterranean forests face various extreme events, such as heat waves, summer drought episodes, storms, and enhanced parasitism (Lindner et al. 2010). As a consequence of these environmental changes (fire risk, pollution, rising temperatures, and summer drought episodes), forest dieback and mortality may increase, as is already the case in western North America (van Mangtem et al. 2009). 
Forest decline and tree mortality still remain poorly understood processes that are often difficult to predict due to the many factors involved and their complex interactions (Sala et al. 2010). High summer temperatures and soil water deficit directly affect photosynthesis, transpiration, respiration, and finally growth. However, these processes may also be indirectly affected by interactions with insect pests or pathogens (Führer 2000). To model forest decline, Manion (1981) developed a conceptual theory based on three different types of factors arising through time: (1) predisposing factors, or long-term factors that weaken trees; (2) inciting factors, or short-term events that trigger the decline; and (3) contributing factors, or factors that substantially reduce the vitality of weakened trees and finally cause mortality. However, there is a lack of quantitative studies on the processes leading to tree death, especially the impact of biotic factors, which play a major role in many cases of forest decline because they regulate host demography and strongly alter the structure of plant communities (Marçais and Bréda 2006).

During recent decades, tree mortality due to parasites has constantly increased because (1) tree weakening following successive drought episodes has led to a decrease of tree resistance mechanisms (Allen et al. 2010), (2) the increasing worldwide trade of forest products has led to on-going introductions of new species of parasites (Haack 2006), and (3) parasites' demography has been strongly favored by drought that lead to a modification of their physiology: an acceleration of their developmental rates (Rouault et al. 2006) and insect detoxication systems, and also they favored mutualistic microorganisms and induced genetic changes in insects (Mattson and Haack 1987).

Understanding the interactions between abiotic and biotic disturbances may be critical for predicting the overall impact of climate change on forest decline. Additionally, vulnerability is expected to be higher for trees living near the edge of their natural distribution, where a small environmental change is likely to negatively impact their fitness (Aitken et al. 2008). In this context, forest insects and diseases today considered minor may become serious, especially for populations at the limit of their host's range, which may display specific features that make them critical model systems for the study of effects of global change on terrestrial ecosystems (Harvell et al. 2002).

In this paper, we aimed to investigate the roles of both plant and insect parasitism in the decline process of southern populations of the silver fir, Abies alba (Miller). Silver fir shows a long history of decline in Mediterranean regions (Cailleret 2011; Oliva and Colinas 2007; Potocic et al. 2005; Bonneau 1989). Over the last 20 years, Mediterranean regions, such as southeastern France, have experienced successive drought episodes (in 1997, 2003, and 2006; Girard et al. 2012) that have weakened trees and favored the development of tree parasites (Rouault et al. 2006). Mistletoe (Viscum album L.) is a hemiparasitic flowering plant that is widely distributed in Europe and Asia. It infects a large variety of deciduous and coniferous tree species, such as silver fir, which is specifically infected by $V$. album ssp. abietis (Wiesb.). Mistletoe collects water and nutrients through the xylem of its host, decreasing the host's hydraulic conductance and reducing photosynthetically tissue and increasing the host's water stress (Rigling et al. 2010). In Pinus sylvestris, Rigling et al. (2010) showed a decrease in ramification rate, needle size, and needle lifespan on branches infected by mistletoe. Consequently, mistletoe may seriously affect timber production by reducing tree height and diameter (Barbu 2009). Bark beetles (Coleoptera: Curculionidae: Scolytinae) have deleterious effects on tree survival, especially for tree populations strongly weakened by climatic or other previous biotic factors (Faccoli et al. 2005). This group includes some of the most injurious insects for trees, especially the treekilling bark beetles, so called because the death of their host tree is normally necessary to the success of their reproduction (Lieutier et al. 2007). Bark beetles are well known for their ability to kill trees by boring galleries in the phloem. They can impact very large areas of forest (Kurz et al. 2008; Liebhold et al. 1995), and their outbreaks are associated with various factors, such as drought, defoliation, forest stand conditions, site characteristics, and windfall (Desprez-Loustau et al. 2006). Bark beetles are generally opportunistic pests, meaning that their establishment success is closely related to the vitality of their hosts. For example, drought-stressed trees are generally less resistant to bark beetles, as they produce less resin and are more attractive and physiologically suitable for insects (Lieutier et al. 2007). In addition, most conifer bark beetles are associated with phytopathogenic fungi, such as Ophiostoma spp. or Leptographium spp., which are known to induce high resin production by trees and to promote vascular wilt or vascular stain diseases (Lieutier et al. 2007).

In this context, the present study focused on the possible interactions between both mistletoe and bark beetle attacks and growth of silver fir in southeastern France. We specifically aimed to disentangle the contribution of predisposing and contributing factors of silver fir decline by determining factors that make trees vulnerable respectively to bark beetles and mistletoe attacks, and by quantifying the impact of these biotic agents on tree growth. For this purpose, we first assessed whether bark beetles and mistletoe parasitized trees display similar or different past growth and tree health status. Then, we compared growth patterns in non-parasitized and parasitized trees. Parasitic pressures on declining silver fir trees were characterized by estimating the infection frequency, biomass, and age of mistletoe along with the diversity, abundance (number of bark beetles per square meter of bark surface area), and phenology of bark 
beetles. Growth of silver fir was assessed by measuring tree-ring widths using a dendrochronological approach. Tree-ring growth is commonly used as an expression of tree productivity, tree health (Manion 1981), and tree responses to past environmental disturbances (Cherubini et al. 2002).

\section{Materials and methods}

\subsection{Study site}

The study was conducted at Mont-Ventoux, France $\left(44^{\circ}\right.$ $\left.11^{\prime} \mathrm{N} ; 5^{\circ} 17^{\prime} \mathrm{E}\right)$, a mountain located in the southwestern Alps (altitude 1,909 m a.s.1.). In the 1850 s, the mountain was deforested due to pastoral and forest overexploitation, but a decrease in grazing combined with pine reforestation efforts (Pinus nigra subsp. nigra Arnold and Pinus sylvestris L.) undertaken in the nineteenth century made it possible for post-pioneer (Sorbus aria L. and Acer opalus Mill.) and shade-tolerant species ( $A$. alba and Fagus sylvatica L.) to gradually colonize the first planted pines. The climate is typical of low-altitude mountains with Mediterranean influences: the mean annual temperature is $9.25{ }^{\circ} \mathrm{C}$ and the mean annual rainfall is $1,068 \mathrm{~mm}$ at $1,000 \mathrm{~m}$ a.s.l. The extractable soil water is low and highly variable, depending on the degree of coarse elements (between $50 \%$ and $80 \%$ ) and on the depth of the bedrock. The experimentation was set up at two sites on the northern face of Mont-Ventoux (Fig. 1). The first experimental site (hereafter named site 1) was distributed along an altitudinal gradient using five plots of $20 \mathrm{~m} \times 20 \mathrm{~m}$ from $995 \mathrm{~m}$ to $1,340 \mathrm{~m}$ elevation (referred to as Dvx1, Dvx2, Dvx3, Dvx4, and Dvx5, respectively) and considering that a downward shift in altitude approximates climate change, i.e., decreases in rainfalls and rising temperatures (Cailleret and Davi 2011). Site 1 was used only for the bark beetle trapping. The second experimental site (named site 2) was used to determine individual vulnerability factors of trees attacked, and to assess the possible impact of these biotic agents on tree growth. Site 2 contained 16 experimental plots (from TC1 to TC16; $20 \mathrm{~m} \times 20 \mathrm{~m}$ ), spaced about $40 \mathrm{~m}$ apart and located along a contour line transect of $638 \mathrm{~m}$ (altitude $1,130 \mathrm{~m}$ a.s.1.), from a crest to an anticlinal valley. It did not intersect with site 1 . Site 2 was chosen in order to reduce climatic variation induced by altitude and to study the impact of topography (covering a large range of soil conditions), edaphic conditions, and biotic factors on silver fir growth and mortality process. On the two study sites, first observations of silver fir decline were noted after the periods of successive summer drought episodes of the years 1997, 2003, and 2006 (Cailleret and Davi 2011).
2.2 Species sampling, measurements, and statistics

\subsubsection{Species sampling}

Silver fir (Abies alba Mill.) is a commonly studied species in dendrochronology due to its sensitivity to disturbance by both abiotic and biotic factors (Manetti and Cutini 2006). All trees $(N=176)$ of site 2, with a DBH above $12.5 \mathrm{~cm}$ and inside the 16 plots, were cored. In addition to these 176 trees, we sampled 51 trees drawing a secondary linear transect along the contour line transect (site 2) and selecting those trees (DBH over $12.5 \mathrm{~cm}$ ) that were outside the 16 studied plots and maximum $2 \mathrm{~m}$ away from the secondary linear transect. One core per tree was taken with an increment borer, at breast height, perpendicularly to the slope $(\mathrm{DBH} ; 1.30 \mathrm{~m})$. The cores were planed with a razor blade. Ring-width (RW, millimeters per year) chronologies were measured at a precision of $0.01 \mathrm{~mm}$ and cross-dated using the CDendro v5.3 and CooRecorder 5.3 softwares (Cybis Elektronik \& Data AB, Sweden). When a core did not reach the pith, the number of missing rings was estimated using the curvature of the innermost rings of the sample. It enabled us to retrieve the distance of each ring to the pith and convert RW data to basal area increment (BAI, square millimeters per year), assuming a circular outline of stem cross-sections. BAI slopes across years were calculated to assess temporal trends in growth using linear regression models.

To characterize tree health status, we followed a protocol established by the French Department of Forest Health (Ministry of Food, Agriculture, Fisheries, Rural Affairs and Land Settlement, France, 2011) that consists in evaluating tree crown damages according to the percentage of both needle chlorosis and defoliation. During September 2008, all trees $(n=227)$ were observed with binoculars from the ground by the same operators. The tree that displayed the lowest percentages of defoliation and needle chlorosis was defined as the healthiest tree. Declining trees were then defined here as trees with a minimum of $20 \%$ defoliation and $20 \%$ needle chlorosis compared with the healthiest one.

To assess whether mistletoe and bark beetles may affect silver fir growth, sub-samples of trees among the 227 trees of site 2 and secondary transect were chosen randomly at a rate of respectively 20 trees for mistletoe studies and of 48 trees for bark beetles studies (Table 1). Trees sub-sampled for bark beetles were different from those sampled for mistletoe. In order to check if the two subsamplings are representative of the whole population, we assigned whole population, mistletoe, and bark beetles sampled trees into three classes of (1) defoliation, (2) diameter, (3) slope of past growth since 2003, and (4) the distance from the crest, and we compared a posteriori the characteristics of the two 


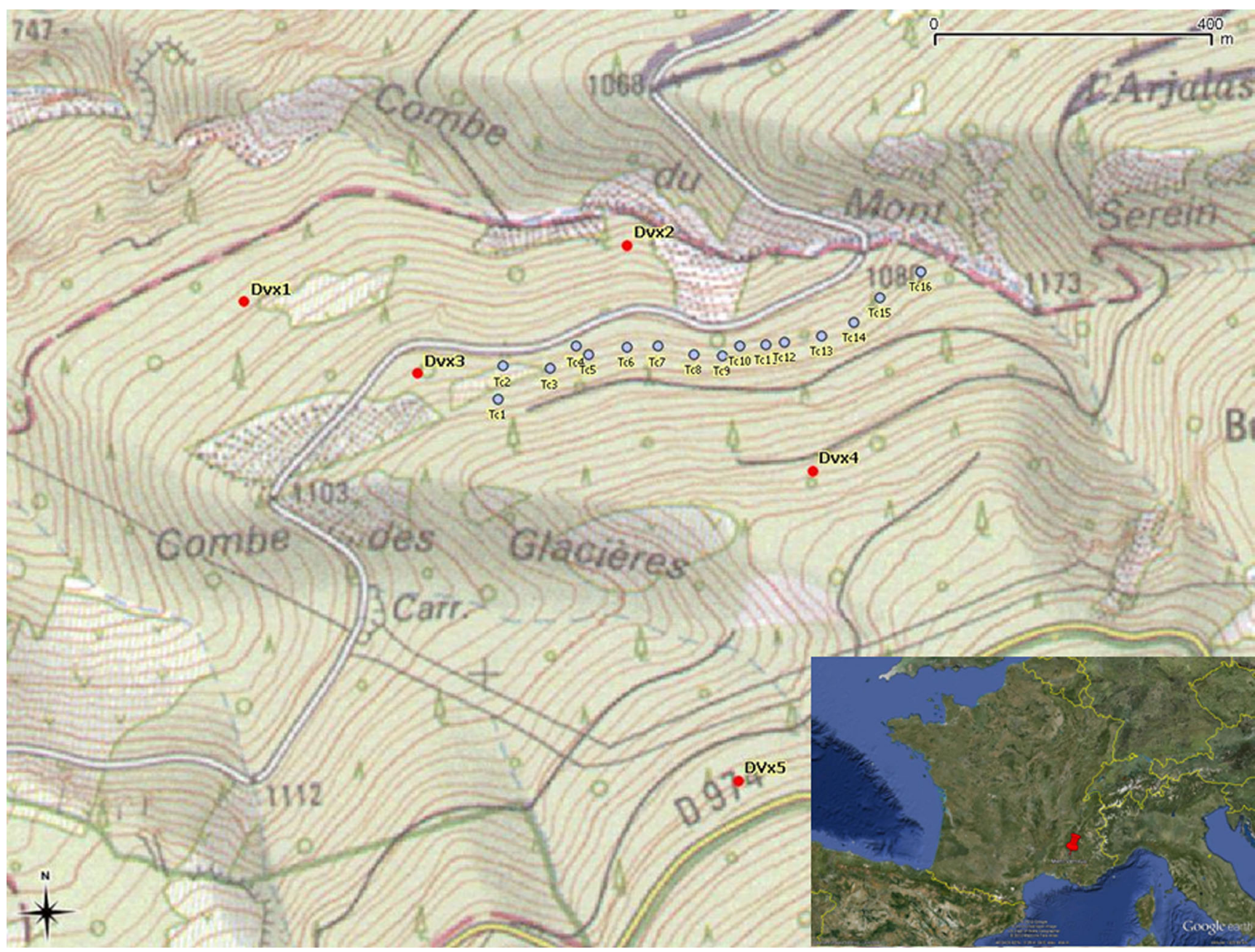

Fig. 1 Location of the two experimental sites on the Mont-Ventoux, France. Site 1 (red points) located along an altitudinal gradient using five plots of $20 \mathrm{~m} \times 20 \mathrm{~m}$ from $995 \mathrm{~m}$ to $1,340 \mathrm{~m}$ elevation (referred to as Dvx1, Dvx2, Dvx3, Dvx4, and Dvx5, respectively). Site 2 (blue

subsamples with those of whole population. We noticed that mistletoe sampled trees overrepresented the low diameters and underrepresented plots located at intermediate distance of the crest, and bark beetle sampled trees only slightly points) contained 16 experimental plots (from TC1 to TC16;20 $\mathrm{m} \times 20$ $\mathrm{m})$, spaced about $40 \mathrm{~m}$ apart and located along a contour line transect of $638 \mathrm{~m}$ (altitude $1,130 \mathrm{~m}$ ), from a crest to an anticlinal valley and which did not intersect site 1

overrepresented trees exhibiting the negative BAI slopes (see differences in the Appendix, Table 7). But the comparisons of mistletoe and bark beetle effects on tree growth should not be impacted by these differences because every
Table 1 Characteristics and growth slopes (BAI slopes from 2003 to 2008) of silver firs sampled for mistletoe and bark beetles on Mont-Ventoux, France

The values are the means \pm standard deviation

\begin{tabular}{lllclr}
\hline & $n$ & Height $(\mathrm{m})$ & Diameter $(\mathrm{cm})$ & \multicolumn{1}{l}{ Age } & \multicolumn{1}{l}{ BAI slope } \\
\hline $\begin{array}{llllr}\text { Population } \\
\text { Mistletoe }\end{array}$ & 227 & $14.7 \pm 2.80$ & $31.3 \pm 10.1$ & $93 \pm 35$ & $-0.000113 \pm 0.0278$ \\
With mistletoe & 12 & $15.0 \pm 3.89$ & $32.2 \pm 12.7$ & $80 \pm 35$ & $0.00108 \pm 0.00422$ \\
Without mistletoe & 8 & $13.7 \pm 2.59$ & $25.5 \pm 9.23$ & $85 \pm 38$ & $-0.0000432 \pm 0.00872$ \\
Total & 20 & $14.6 \pm 3.53$ & $30.2 \pm 11.9$ & $81 \pm 35$ & $0.000745 \pm 0.00570$ \\
Bark beetles & & & & & \\
With bark beetles & 12 & $14.0 \pm 3.12$ & $28.8 \pm 11.6$ & $89 \pm 33$ & $-0.00780 \pm 0.0427$ \\
Without bark beetles & 36 & $14.6 \pm 2.40$ & $31.1 \pm 8.65$ & $94 \pm 38$ & $0.0184 \pm 0.0603$ \\
Total & 48 & $14.5 \pm 2.54$ & $30.6 \pm 9.27$ & $93 \pm 37$ & $0.0125 \pm 0.0575$ \\
\hline
\end{tabular}


type of tree category was represented in the two sub-samples (in terms of defoliation classes, diameter classes, etc.).

\subsubsection{Mistletoe measurements}

The 20 trees were classified according to their infection level with class 0 : absence of mistletoe, class 1: low infection with high frequency of bushes on lateral branches, class 2: moderate infection with many bushes in the crown and drying branches, and class 3: strong infection with bushes growing all over the crown and stem (Barbu 2009). In spring 2010, these 20 trees, 14 infected trees and six uninfected trees, were climbed to make sure that uninfected trees were uninfected and all mistletoes on each infected tree were counted according to their age classes. Mistletoe age was determined by counting growth units. A growth unit, corresponding to 1 year, is the portion of stem developed during 1 year (Noetzli et al. 2003). We categorized mistletoe individuals into the following age classes: $2-5$ years old, $6-$ 10 years old, and more than 10 years old.

Due to the difficulty of harvesting all mistletoes on a tree, 20 mistletoes per age class were collected on the 14 infected trees. We aimed to assess the total mistletoe biomass on each tree with an allometric model. Mistletoe biomass was measured after drying at $60{ }^{\circ} \mathrm{C}$ for $72 \mathrm{~h}$. Stem diameter and biomass data per age class of mistletoe were transformed using a logarithmic transformation and we constructed a linear model of biomass prediction based on mistletoe age and stem diameter to predict the total mistletoe biomass for each sampled tree (Eq. 1).

$$
\begin{aligned}
B_{\text {mist }} & =a \times \log \left(\text { Diam }_{\text {mist }}\right)+b \times \log \left(\text { Age }_{\text {mist }}\right) \\
& +c \times\left[\log \left(\text { Age }_{\text {mist }}\right) \times \log \left(\text { Diam }_{\text {mist }}\right)\right]+\varepsilon
\end{aligned}
$$

where Diam mist $_{\text {is }}$ the stem diameter of the mistletoe plant and Age mist $_{\text {is }}$ the age class of the mistletoe plant.

\subsubsection{Bark beetle measurements}

Contrary to mistletoe, we did not know a priori if bark beetles infested the 48 sampled trees. We saw principally entrance holes on branches and stem bark patches, but we did not know if bark beetles were present. For the 48 trees, we sampled two upper (sampled at approximately $13 \mathrm{~m}$ height with a saw) and two lower crown branches (sampled at around $3 \mathrm{~m}$ to $5 \mathrm{~m}$ height with a saw), and two stem bark patches of approximately $9 \times 10 \mathrm{~cm}$ (sapwood and bark was sampled as a single piece at DBH and at around $13 \mathrm{~m}$ height with a chisel), without particular compass orientation and of similar sizes (upper branches-mean diameter $=0.03 \pm$ $0.007 \mathrm{~m}$, mean length $=0.94 \pm 0.51 \mathrm{~m}$, mean area $=0.08 \pm$ $0.05 \mathrm{~m}^{2}$; lower branches - mean diameter $=0.03 \pm 0.007 \mathrm{~m}$, mean length $=0.90 \pm 0.39 \mathrm{~m}$, mean area $\left.=0.08 \pm 0.03 \mathrm{~m}^{2}\right)$. We also determined the mean bark surface area of removed patches $\left(0.009 \pm 0.003 \mathrm{~m}^{2}\right)$. Branches and stem bark patches were maintained in the laboratory at room temperature (approximately $20{ }^{\circ} \mathrm{C}$ ) in transparent and ventilated Plexiglas boxes, in which insect emergences were recorded daily. Emerging individuals were collected, killed by storage at $-18{ }^{\circ} \mathrm{C}$ for $24 \mathrm{~h}$, and stored in $95 \%$ alcohol for identification. After emergence stopped, branches and bark samples were dissected to locate insect galleries and to detect non-emerged or dead individuals. The emergence data were used to assess bark beetle diversity, abundance (number of insects per square meter of bark), sex ratios, and plot infestation (percentage of infested trees per plot). The diversity and abundance of bark beetle species were compared on the intra-plot scale (as a function of tree health and tree characteristics) and the inter-plot scale (as a function of location on the transect and the number of dead trees within a radius of $20 \mathrm{~m}$ around the studied tree).

Additional bark beetle sampling was carried out in both site 1 and site 2 using multi-directional interception traps based on a cross-vane window flight trap with a cumulative panel area of $1 \mathrm{~m}^{2}$. Trap containers were half-filled with water for insect conservation, and a non-attractive detergent was added to reduce surface tension. Five traps were set up in 2010 (from 16 March to 01 July) at site2, and four traps were placed in the Dvx5 plot (site 1) with a spacing distance of $50 \mathrm{~m}$. All traps were collected weekly. Nomenclature was used in accordance with the Fauna Europaea database (http://www.faunaeur.org). Meteorological data (temperature and precipitation) were recorded using HOBO Pro V2 data loggers (Prosensor, France) located at DBH in each of the five plots along the altitudinal gradient (site 1). The seasonal dynamics of bark beetle flight was characterized in each site (number of bark beetles per trap and per week), and the impact of local meteorological conditions (temperature and precipitation) was analyzed using Pearson correlation coefficients, accounting for the altitude.

\subsubsection{Individual vulnerability factors of trees attacked by bark beetles and mistletoe}

The relationships between both abundance of bark beetles and mistletoe infection and tree characteristics were assessed using analysis of variance (ANOVA) and Pearson correlation test performed on data collected on the contour line transect (site 2). Trees were classified according the following characteristics:

- Dendrometrical characteristics (tree diameter, height, age at DBH from tree ring counting, social status with 
dominant and dominated trees, length, and branch diameter),

- Tree health status (healthy trees were defined as trees with a percentage of defoliation and needle chlorosis lower than $20 \%$, declining trees as trees with a minimum of $20 \%$ defoliation and $20 \%$ needle chlorosis compared with the healthiest one, and recently dead trees were defined as trees with $100 \%$ of needle chlorosis and defoliation),

- A distance-dependent competition index (Martin-Ek index-Martin and Ek 1984; Eq. 2) calculated by increasing the neighborhood radius around each studied tree $(2 \mathrm{~m}, 4 \mathrm{~m}$, and $8 \mathrm{~m})$.

$\operatorname{Martin}-E k_{i}=\frac{1}{d b h_{i}} \sum_{j=1}^{n_{i}} d b h_{j} \exp \left[\frac{-16 \times d_{i j}}{d b h_{i}+d b h_{j}}\right]$

where $\mathrm{dbh}_{i}$ and $\mathrm{dbh}_{j}$ are the diameter at breast height of individual $i$ and $j$, respectively, $n_{i}$ the total number of competitors, and $d_{i j}$ the distance between individual $i$ and $j$.

To understand interactions between tree growth variables and mistletoe biomass or bark beetle abundance, linear regression models were used to assess temporal trends in growth rates for the last 2 to 11 years of BAI (LocReg2 to LocReg11=2006-2007 to 1997-2007). We calculated the slope of these linear regressions to characterize the growth trend, with BAI as the dependent variable. Calculating growth slopes for increasing periods (2006-2007 to 19972007) allowed us to relate growth variations to the dates of mistletoe infection or bark beetle attack 2 years earlier. For mistletoe, the infection has started in 1992, but we used only the last 10 years because mistletoe infection peak was in 1997.

For each parasite, we compared also mean BAI of tree population $(N=227)$ and the mistletoe and bark beetles subsamples with Student's $t$ test.

\subsubsection{Modeling the effect of mistletoe infection on tree growth}

The effect of mistletoe infection was also assessed comparing BAI profiles for the period 1996-2007 with a model in which BAI was simulated for the period 1996-2007 accounting only for climatic variables and ring autocorrelations. For each tree, the model was constructed using a generalized linear model that modeled BAI for the period 1964-1996 (without infection) as a function of ring width of the previous years and climatic variables (precipitation $P$, mean temperature $T_{\text {mean }}$, minimum temperature $T_{\min }$, and maximum temperature $\left.T_{\max }\right)$. Model selection was done using AIC
(Akaike Information Criterion). Growth from 1996 to 2007 was then simulated $\left(\mathrm{BAI}_{\mathrm{s}}\right)$ for each tree and compared to measured growth $\left(\mathrm{BAI}_{\mathrm{m}}\right)$ using Student's $t$ test.

Statistical analyses were performed using the statistical software R (R Development Core Team 2005) (packagesMASS, stats, and ade4) at a significance threshold of $5 \%$.

\section{Results}

3.1 Relationship between stem diameter, age, and biomass of mistletoe

The mean age of the $V$. album specimens was 8 years, and the maximum age was 18 years. Mistletoe stem diameter and biomass were highly correlated (Pearson correlation test, $r=0.95, t=25.42, d f=64 ; p<0.001)$, but such a correlation varied significantly between age classes of mistletoe (ANOVA, $d f=2, F$ value $=596.29 ; p<0.001$; Table 2 ). A positive correlation between age and biomass was also found (Pearson correlation test, $r=0.88, t=15.34, d f=64 ; p$ $<0.001$; Fig. 2).

\subsection{Bark beetles sampling on silver firs}

Twelve of the 48 sampled trees were attacked by bark beetles, among which six trees were attacked on branches only. A total of 520 bark beetles emerged from the tree branches surveyed in the laboratory after larval development. Among the five species that were found, Pityophthorus pityographus Ratz. was by far the dominant one in terms of total number of insects ( $74.2 \%$ of all emerging insects), followed by Pityokteines vorontzovi Jac. (13.3\%), Pityokteines spinidens Reitt. (11.5\%), Cryphalus abietis Ratz. (0.8\%), and Crypturgus cinereus Herbst (0.2 \%). The bark beetle species showed diverging distributions at tree scale: $P$. pityographus (381 insects $\left./ \mathrm{m}^{2}\right), P$. vorontzovi $\left(106\right.$ insects $\left./ \mathrm{m}^{2}\right)$, C. abietis (14 insects $/ \mathrm{m}^{2}$ ), and C. cinereus ( 7 insects $/ \mathrm{m}^{2}$ ) were primarily found in the upper crown where branches had thin bark, whereas P. spinidens (480 insects $/ \mathrm{m}^{2}$ ) was more abundant on the stem where the bark is thicker (Table 3). Sampling was done in spring (March to April 2010) and emergences in the laboratory continued until May, thus this period covered

Table 2 Statistics of linear regressions performed on stem diameter and biomass by age classes of mistletoes on Mont-Ventoux, France

\begin{tabular}{llll}
\hline Age class & $2-5$ years & $6-10$ years & $>10$ years \\
\hline Slope $( \pm \mathrm{IC})$ & $3.14 \pm 0.101$ & $2.62 \pm 0.116$ & $1.57 \pm 0.077$ \\
Intercept & -4.11 & -2.91 & 0.215 \\
$R^{2}$ & 0.854 & 0.755 & 0.755 \\
\hline
\end{tabular}

IC $95 \%$ confidence interval, intercept of linear regression $=-2.27$ 


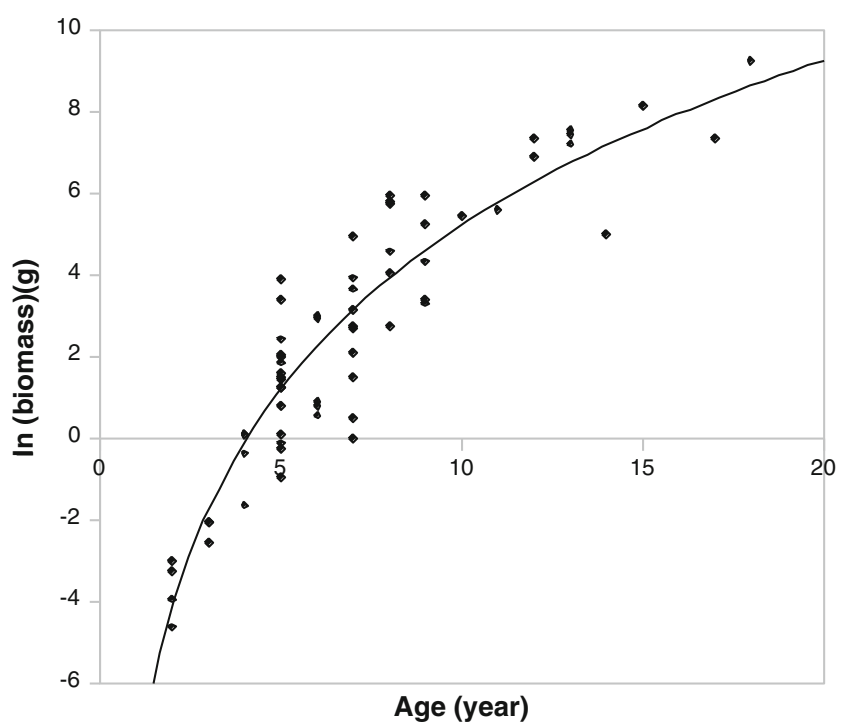

Fig. 2 Relationship between mistletoe age and log-transformed mistletoe biomass, Mont-Ventoux, France. The equation of trend curve was a logarithmic form: $f(x)=5.75 \ln (x)-8.01 ; R^{2}=0.85$

male and female emergence for these five species. The sex ratio showed variation between species: it was quite balanced in both $P$. pityographus and P. vorontzovi (1.02 and 0.98 , respectively), while an excess of females was found in $P$. spinidens (0.49). The samples of $C$. cinereus and C. abietis were too small to estimate the sex ratios.

Three groups of insect species could be distinguished according to tree health status as follows: (1) healthy trees $(N=29)$ had only a few individuals of $P$. vorontzovi $(55 \%)$, P. pityographus $(27 \%)$, and $C$. abietis $(18 \%)$ on their branches; (2) declining trees $(N=14)$ were mainly attacked on the stems by P. spinidens $(53 \%$ ) and by $P$. vorontzovi (44\%) in the upper part of the crown; and (3) dead trees $(N=5)$ were mainly colonized by $P$. pityographus $(81 \%), P$. vorontzovi (10\%), and P. spinidens (9\%) on both branches and stems (Fig. 3). However, in our study, tree health status was measured in 2008 and emergence data was collected in 2010 , so some trees considered as healthy trees in 2008 may have been dead trees in 2010 . On site 2 , trees infested by bark beetles were located in plots with high tree mortality (Pearson correlation test, $r=0.56, t=2.45, d f=13 ; p<0.05$ ).

3.3 Multi-directional trapping of insects in silver fir plots

Multi-directional trapping of flying insects on the two sites resulted in the collection of 160 bark beetle individuals belonging to 16 species, and 97 ambrosia beetle individuals belonging to one species Xyloterus lineatus. Among these 16 bark beetle species, Hylastes attenuatus was by far the dominant species ( $26 \%$ of individuals), followed by $P$. spinidens Reitt. (16\%), C. piceae (12\%), P. pityographus, and $P$. vorontzovi (10\% for each respectively). The total number of C. abietis, C. cinereus, Ernopocerus fagi (Fabricius), Hylastes ater (Paykull), Hylurgops glabratus (Zetterstedt), Hylurgops palliatus (Gyllenhal), Orthotomicus laricis (Fabricius), Pityophthorus pubescens (Marsham), Thamnurgus characiae (Rosenhauer), Tomicus piniperda (L.), and T. minor (Hartig) were lower than $8 \%$. Significant differences in trap contents were found between the two altitudes. Fourteen bark beetle individuals were trapped in the Dvx5 plot (four traps; altitude 1,340 m a.s.l.) between April 30 and July 1, 2010 (C. piceae, E. fagi, H. ater, H. attenuatus, P. pityographus, and T. minor), whereas 146 bark beetles were trapped from April 8 to July 1, 2010 on the contour line transect (five traps; altitude $1,130 \mathrm{~m}$ a.s.1.). The seasonal flight activity of bark beetles (number of bark beetles per trap and per week) was positively related to mean weekly temperatures (Pearson correlation test, $r=0.57, t=2.77, d f=16 ; p<0.05)$, while there was no significant effect of precipitation $(p=0.35)$.

3.4 Vulnerability factors of trees attacked by bark beetles

Tree population DBH ranged from approximately 12.7 to $57.3 \mathrm{~cm}$. Most of the tree population $(n=227)$ was in the 25.4-31.8-cm-diameter class and the number of trees per diameter class decreased with increasing diameter class. Trees with bark beetles were divided into three diameter classes: $12.7-19 \mathrm{~cm}, 19-25.4 \mathrm{~cm}$, and $38.1-44.5 \mathrm{~cm}$. Trees
Table 3 Abundance of bark beetles species (number of insects $/ \mathrm{m}^{2}$ of bark) according to their tree location (stem bark patches or branches) on 12 infested silver firs of the contour line transect on Mont-Ventoux, France

PSPI Pityokteines spinidens, CCIN Crypturgus cinereus, PPIT Pityophthorus pityographus, PVOR Pityokteines vorontzovi, CABIE Cryphalus abietis

\begin{tabular}{|c|c|c|c|c|}
\hline \multirow[t]{2}{*}{ Species } & \multicolumn{2}{|c|}{ Stem bark patches $(N=24)$} & \multicolumn{2}{|c|}{ Branches $(N=24)$} \\
\hline & Lower patches & Upper patches & Lower branches & Upper branches \\
\hline Total & 526 & 241 & 60 & 215 \\
\hline PSPI & 526 & 389 & 10 & 57 \\
\hline CCIN & 0 & 0 & 0 & 7 \\
\hline PPIT & 0 & 0 & 45 & 493 \\
\hline PVOR & 0 & 93 & 125 & 102 \\
\hline CABIE & 0 & 0 & 0 & 14 \\
\hline
\end{tabular}




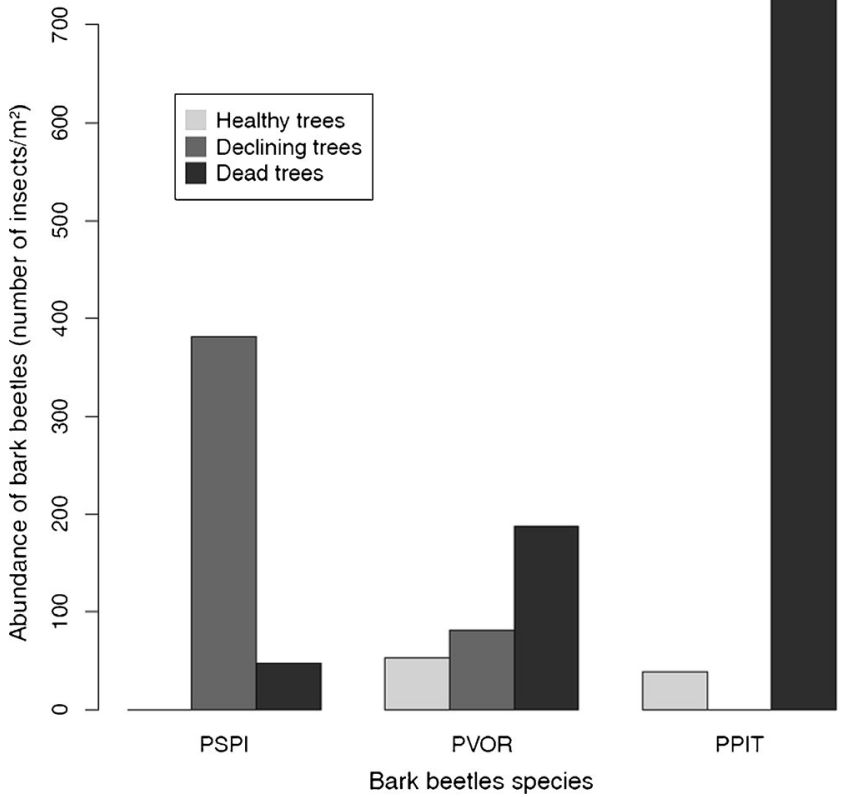

Fig. 3 Groups of bark beetle species according to silver fir health status on the contour line transect and in the Dvx5 plot on MontVentoux, France. Dead $(N=5)$ and declining trees $(N=14)$ are in black and in gray, respectively. PSPI Pityokteines spinidens, PPIT Pityophthorus pityographus, PVOR Pityokteines vorontzovi, CCIN Crypturgus cinereus, CABIE Cryphalus abietis. CCIN and CABIE are not represented here because of their low abundance (dead trees $=1 \mathrm{CCIN}$ and 1 CABIE; declining trees $=1$ CABIE)

with higher diameters displayed less bark beetles (Pearson correlation test, $r=-0.36, t=-2.59, d f=45 ; p<0.05)$. A positive effect on the abundance of bark beetles was seen for bigger and longer upper crown branches (Table 4). The abundance of bark beetles was positively correlated with percentages of both needle chlorosis (Pearson correlation test, $r=0.51, t=3.99, d f=44 ; p<0.001)$ and crown defoliation (Pearson correlation test, $r=0.42, t=3.12, d f=44 ; p<$ 0.01 ) (Table 4). Bark beetle abundance was not affected by tree density and tree social status. Interestingly, trees attacked by bark beetles were not infected by mistletoe.

Trees infested with bark beetles in 2008 displayed a lower growth rate during 1950-2008 than the average for whole population (Student's $t$ test, $t=5.58, d f=211.17 ; p<$ $0.001)$ and the average for non-infested trees (Student's $t$ test, $t=-4.27, d f=1035 ; p<0.001$ ) (Table 1 and Fig. 4). Similarly, BAI slope values from 2003 to 2008 were negative in infested trees, while non-infested trees showed increasing radial growth (a positive BAI slope value) during the same period (Table 1). However, there was no linear correlation between the presence of bark beetles and either growth slopes or mean BAI.

\subsection{Vulnerability factors of trees infected by mistletoe}

The social status of trees had a significant influence on parasitism by mistletoe: the infection level was higher on dominant $(N=9)$ than on suppressed trees $(N=11)$ (ANOVA, $d f=2$, $F$ value $=12.16 ; p<0.001)$. Moreover, competing trees had less mistletoe than isolated ones when using competition indices with 2 and $4 \mathrm{~m}$ radii (ANOVA, $d f=1, F$ value $=$ $10.15 ; p<0.01$; ANOVA, $d f=1, F$ value $=26.79 ; p<0.001$, respectively). But using a competition index with an $8-\mathrm{m}$ radius, there was no effect of competition on mistletoe infection (ANOVA, $d f=1, F$ value $=2.05 ; p=0.15$ ). Infected silver firs were taller (Student's $t$ test, $t=16.27, d f=22.36 ; p<0.001$ ) and had a larger diameter (Student's $t$ test, $t=11.32, d f=19 ; p<$ $0.001)$ than non-infected ones, and they had a higher average BAI (Student's $t$ test, $t=-11.78, d f=85.03 ; p<0.001$ ) from 1950 to 2008 (Table 1). Evolution of BAI with time suggested that since 1950 trees infected by mistletoe had higher growth rates (Student's $t$ test, $t=14.34, d f=96.15 ; p<0.001$ ) than those of non-infected trees (Student $t$ test, $t=15.20, d f=$ 112.18; $p<0.001$ ) (Fig. 5). Similarly, BAI slope values from 2003 to 2008 were more negative for non-infected trees than for infected trees (Table 1).

3.6 Modeling the impact of mistletoes on tree growth

During recent years, between 2001 and 2007, mistletoe biomass was significantly correlated with growth parameters, mean BAI and growth slopes (Table 5). During this

Table 4 Analysis of variance of the effect of dendrometrical and health tree status parameters on the abundance of bark beetles (number of insects/ $\left.\mathrm{m}^{2}\right)$ in silver firs $(N=48)$ on Mont-Ventoux, France

\begin{tabular}{|c|c|c|c|c|c|c|c|c|c|c|c|c|}
\hline & \multicolumn{6}{|c|}{ Dendrometrical parameters } & \multicolumn{6}{|c|}{ Health status parameters } \\
\hline & \multicolumn{2}{|c|}{ Branch diameter } & & \multicolumn{2}{|c|}{ Branch size } & & \multicolumn{2}{|c|}{$\%$ Needle chlorosis } & & \multicolumn{2}{|c|}{$\%$ Defoliation } & \\
\hline & $F$ & $p$ & & $F$ & $p$ & & $F$ & $p$ & & $F$ & $p$ & \\
\hline High branch & 7.67 & 0.00818 & $* *$ & 4.33 & 0.0431 & $*$ & 0.254 & 0.617 & NS & 0.022 & 0.883 & NS \\
\hline Low branch & 0.00150 & 0.969 & NS & 0.396 & 0.533 & NS & 25.2 & $<0.001$ & $* * *$ & 32.7 & $<0.001$ & $* * *$ \\
\hline
\end{tabular}

$\mathrm{ddl}=1 ; N S$ non significant

${ }^{*} p<0.05,{ }^{* *} p<0.01, * * * p<0.001$ 
Fig. 4 Mean BAI chronology of a population of silver firs (gray; $N=227$ ), sub-samples with bark beetles (dotted line; $N=12$ ), and sub-samples without bark beetles (black; $N=36$ ) during the last 60 years (1950 to 2010) on a contour line transect on Mont-Ventoux, France. The values of means $\left(\mathrm{mm}^{2} /\right.$ year) \pm standard errors were: population $=904 \pm 21.8$; subsamples with bark beetles $=731 \pm 23.8$; subsamples without bark beetles $=850 \pm 25.2$

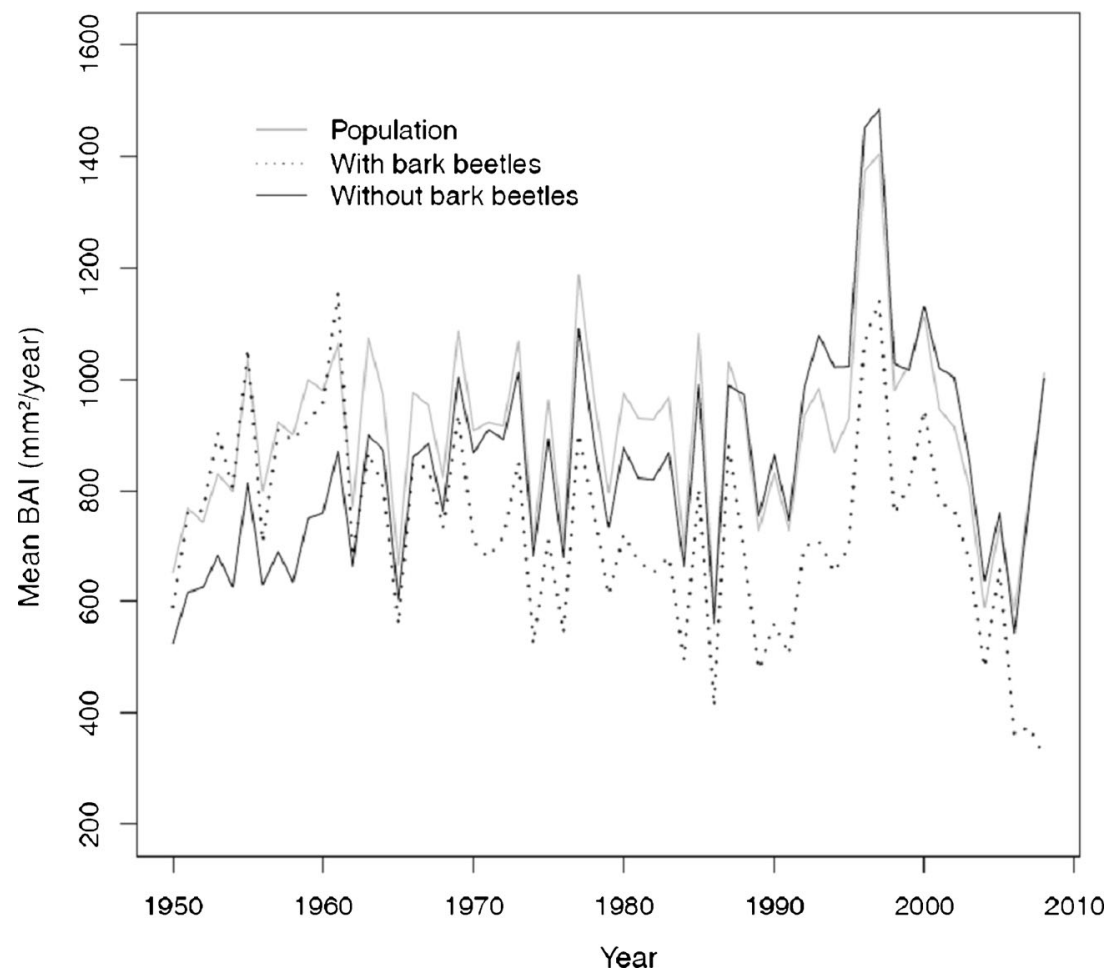

period, growth slopes were negative, which indicated a decrease in tree growth for most trees. To confirm this hypothesis, we compare the BAI measurements to the generalized linear model that simulate BAI for the period 1996-2007 accounting only for climatic variables and ring autocorrelations. During the 1996-2007 period, the simulated BAI of infected trees was higher than the measured BAI for all classes of mistletoe infection, but these differences were significant only for class 1 of mistletoe infection (Fig. 6 and Table 6). The results confirm that mistletoe infection negatively impacted tree growth.
Fig. 5 Mean BAI chronology of a population of silver firs (gray; $N=227$ ), sub-samples with mistletoe (dotted line; $N=$ 14), and sub-samples without mistletoe (black; $N=6$ ) on a contour line transect on MontVentoux, France. The values of means $\left(\mathrm{mm}^{2} /\right.$ year $) \pm$ standard errors were as follows: population $=904 \pm 21.8$, subsamples with mistletoe $=989 \pm$ 30.5 , and sub-samples without mistletoe $=588 \pm 15.2$

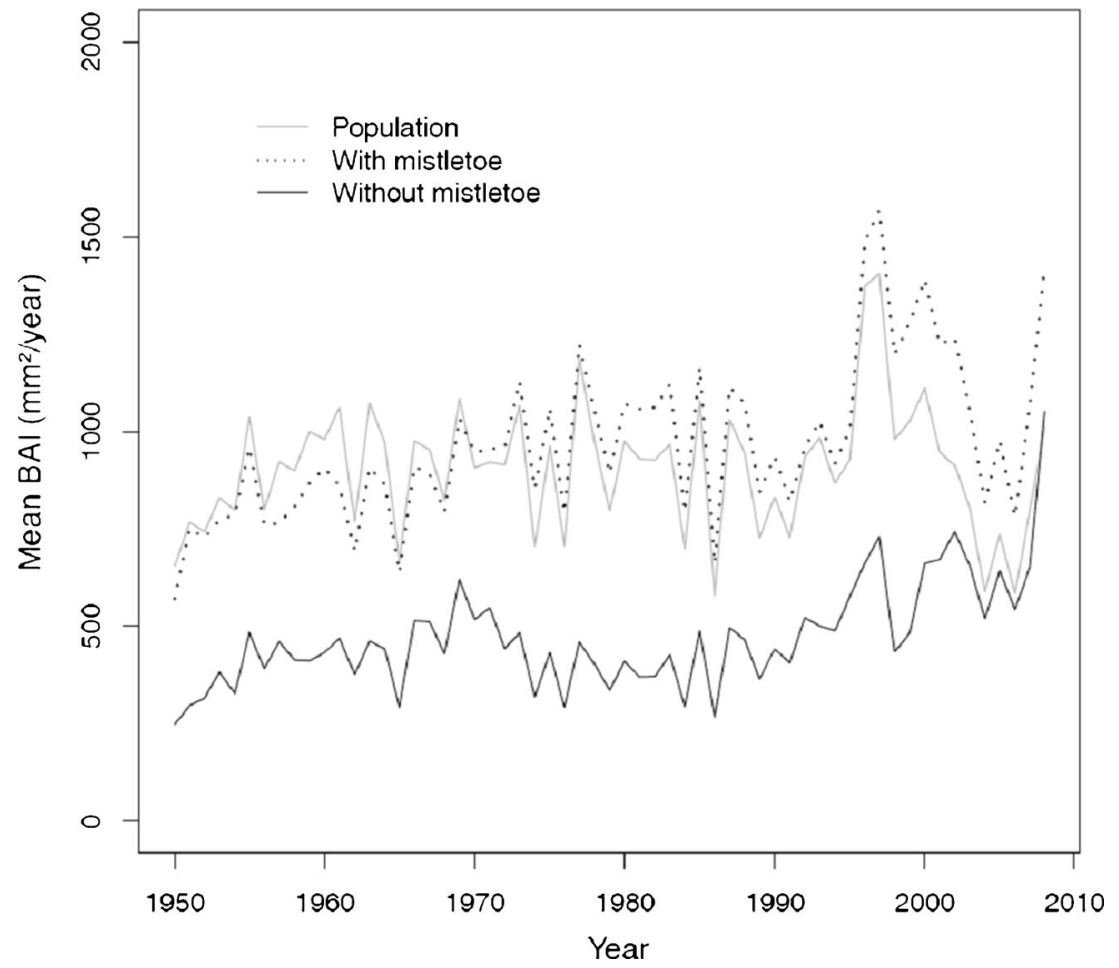


Table 5 Statistics of linear regressions performed on mistletoe biomass and growth variables on Mont-Ventoux, France, from 1997 to 2007

\begin{tabular}{|c|c|c|c|c|c|c|c|c|}
\hline \multirow{2}{*}{$\begin{array}{l}\text { Interval } \\
\text { (LocReg) }\end{array}$} & \multicolumn{4}{|c|}{ Growth slope } & \multicolumn{4}{|c|}{ Mean BAI } \\
\hline & Slope & Adjusted $R^{2}$ & $p$ & & BAI & Adjusted $R^{2}$ & $p$ & \\
\hline 2007-2006 (LocReg2) & 28.3 & 0.0397 & 0.204 & NS & 896 & 0.316 & 0.00720 & * \\
\hline 2007-2005 (LocReg3) & 45.9 & 0.0398 & 0.204 & NS & 740 & 0.551 & $<0.001$ & $* * *$ \\
\hline 2007-2004 (LocReg4) & -5.65 & 0.196 & 0.0330 & $*$ & 970 & 0.538 & $<0.001$ & $* * *$ \\
\hline 2007-2003 (LocReg5) & -47.0 & 0.216 & 0.0259 & * & 1162 & 0.495 & $<0.001$ & $* * *$ \\
\hline 2007-2002 (LocReg6) & -55.6 & 0.141 & 0.0629 & NS & 1152 & 0.370 & 0.00337 & $* *$ \\
\hline 2007-2001 (LocReg7) & -71.1 & 0.0462 & 0.189 & NS & 1349 & 0.164 & 0.0480 & $*$ \\
\hline 2007-2000 (LocReg8) & -66.6 & -0.00675 & 0.361 & NS & 1246 & 0.0916 & 0.111 & NS \\
\hline 2007-1999 (LocReg9) & -55.8 & -0.0260 & 0.471 & NS & 1156 & 0.104 & 0.0957 & NS \\
\hline 2007-1998 (LocReg10) & -73.8 & -0.0526 & 0.755 & NS & 1737 & -0.0356 & 0.545 & NS \\
\hline 2007-1997 (LocReg11) & -74.1 & -0.0588 & 0.988 & NS & 1548 & -0.0485 & 0.688 & NS \\
\hline
\end{tabular}

The growth slope is presented in units of square millimeter per year. LocReg was the slopes of linear regressions fitted over the last 2 to 11 previous years of BAI

$N S$ non-significant

${ }^{*} p<0.05, * * p<0.01, * * * p<0.001$

\section{Discussion}

4.1 Contrasts in tree choice between mistletoe and bark beetles

The effects of mistletoes on tree productivity have been previously examined (Geils and Hawksworth 2002; Noetzli et al. 2003). Here we showed significant interactions between individual tree characteristics (dendrometrical features, tree health status, and competition indices) and vulnerability of a silver fir population to mistletoe infection. Mistletoe settled principally on healthy trees, which had a better past growth than non-infected ones. This may result from the dependence of mistletoe fitness to the health status of its host, as the parasite collects water and nutrients through the xylem (Rigling et al. 2010). Moreover, we
Fig. 6 Growth models of silver fir on Mont-Ventoux, France, following comparisons of observed and simulated growth (Mean BAI) between infected $(N=12)$ and uninfected trees $(N=8)$ using Student's $t$ test ( $p<$ $0.05)$. The $x$-axis indicates the infection level (class 0, absence of mistletoe; class 1 , low infection; class 2 and 3, moderate and strong infection). Different letters indicate a significant difference. $N S$ non-significant; ${ }^{*} p<0.05$; the error bars represent the standard error

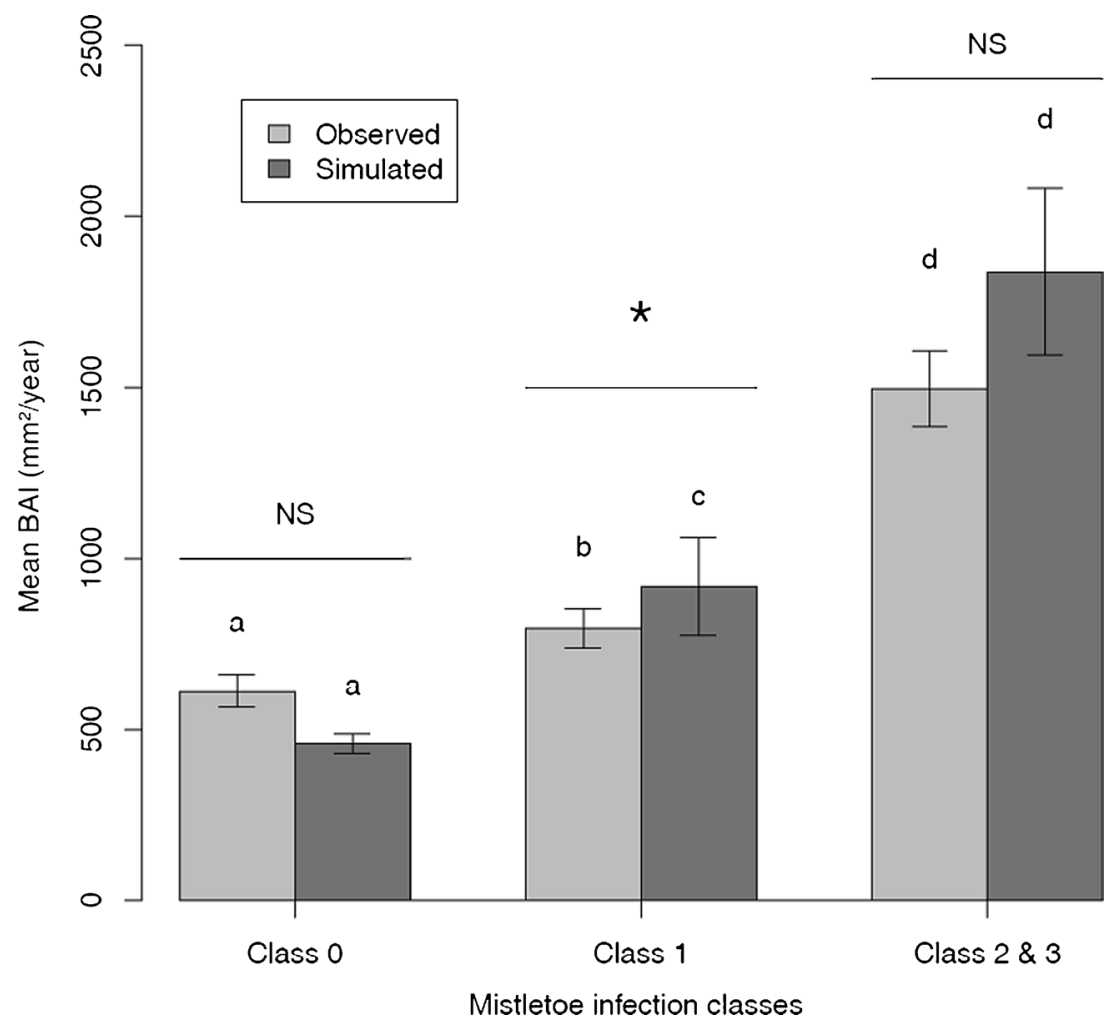


Table 6 Growth models of silver fir on Mont-Ventoux, France, following comparisons of growth between infected $(N=14)$ and uninfected trees $(N=6)$ using Student's $t$ test $(p<0.05)$

\begin{tabular}{|c|c|c|c|c|c|c|c|c|c|c|c|c|}
\hline \multirow[b]{2}{*}{ Tree } & \multirow[b]{2}{*}{ Class } & \multirow[b]{2}{*}{ Infection year } & \multicolumn{4}{|c|}{ Model 1964-1996 } & \multicolumn{6}{|c|}{ Student's $t$ test 1997-2007 } \\
\hline & & & $R^{2}$ & $F$ & $p$ & & $t$ & $d f$ & $p$ & & $\mathrm{BAI}_{\mathrm{m}}$ & $\mathrm{BAI}_{\mathrm{s}}$ \\
\hline TC4_S7 & 0 & - & 0.480 & 4.70 & 0.00147 & $* *$ & 3.15 & 19.9 & 0.00498 & $*$ & 839 & 650 \\
\hline TC12_S6 & 0 & - & 0.429 & 5.00 & 0.00158 & $* *$ & 1.88 & 19.9 & NS & NS & 740 & 526 \\
\hline TC13_S12 & 0 & - & 0.332 & 3.27 & 0.0131 & * & -1.42 & 16.7 & NS & NS & 231 & 251 \\
\hline TC15_S13 & 0 & - & 0.451 & 7.57 & $<0.001$ & $* * *$ & 2.04 & 12.5 & NS & NS & 693 & 457 \\
\hline TCR14 & 0 & - & 0.594 & 4.89 & 0.00346 & $* *$ & 2.50 & 13.2 & 0.0262 & $*$ & 556 & 403 \\
\hline TCR49 & 0 & - & 0.952 & 62.2 & $<0.001$ & $* * *$ & 3.19 & 10.2 & 0.00931 & $* *$ & 2,600 & 412 \\
\hline TCR58 & 1 & 1997 & 0.235 & 4.27 & 0.0129 & $*$ & -0.28 & 14.4 & NS & NS & 735 & 765 \\
\hline TC8_S3 & 1 & 1997 & 0.0900 & 2.61 & NS & NS & - & - & - & - & - & - \\
\hline TC3_S17 & 1 & 1999 & 0.375 & 7.40 & 0.000793 & $* *$ & -1.39 & 18.8 & NS & NS & 677 & 778 \\
\hline TC1_S7 & 1 & 2001 & 0.859 & 25.4 & $<0.001$ & $* * *$ & 3.41 & 18.6 & 0.00299 & $* *$ & 814 & 710 \\
\hline TC7_S8 & 1 & 2001 & 0.402 & 3.15 & 0.0118 & $*$ & 6.72 & 19.8 & $<0.001$ & $* * *$ & 816 & 205 \\
\hline TCR16 & 1 & 2002 & 0.376 & 5.83 & 0.00153 & $* *$ & -4.71 & 11.2 & 0.000600 & $* *$ & 1,426 & 2,504 \\
\hline TCR45 & 1 & 2004 & 0.583 & 9.95 & $<0.001$ & $* * *$ & -2.94 & 12.9 & 0.0114 & $*$ & 515 & 727 \\
\hline TCR38 & 2 & 1997 & 0.579 & 7.31 & $<0.001$ & $* * *$ & -5.81 & 19.9 & $<0.001$ & $* * *$ & 2,262 & 3,284 \\
\hline TCR5 & 2 & 1997 & 0.868 & 31.0 & $<0.001$ & $* * *$ & -4.42 & 10.7 & 0.00110 & $* *$ & 1,774 & 3,844 \\
\hline TC3_S10 & 2 & 2001 & 0.539 & 5.16 & 0.000702 & $* *$ & 1.11 & 19.7 & NS & NS & 846 & 740 \\
\hline TC4_S11 & 2 & 2001 & 0.407 & 8.32 & $<0.001$ & $* * *$ & 3.11 & 17.8 & 0.00613 & $*$ & 995 & 805 \\
\hline TC15_S1 & 3 & 1992 & 0.367 & 5.63 & 0.00186 & $* *$ & 3.80 & 16.5 & 0.00148 & $* *$ & 2,048 & 1,363 \\
\hline TCR13 & 3 & 1996 & 0.331 & 4.97 & 0.00373 & $* *$ & -0.813 & 11.8 & NS & NS & 1,560 & 1,774 \\
\hline TCR6 & 3 & 2000 & 0.822 & 19.5 & $<0.001$ & $* * *$ & -0.770 & 16.5 & NS & NS & 979 & 1,037 \\
\hline
\end{tabular}

For each tree, $\mathrm{BAI}_{\mathrm{m}}$ and $\mathrm{BAI}_{\mathrm{s}}$ were the mean value of observed and simulated growth, respectively. For each tree, class was the infection level (class $0=$ absence of mistletoe, class $1=$ low infection, class $2=$ moderate infection, class $3=$ strong infection) and infection year was the starting year of mistletoe infection

$N S$ non-significant

${ }^{*} p<0.05,{ }^{* *} p<0.01, * * * p<0.001$

found that mistletoe infection was higher on isolated and dominant trees, probably because they attract birds, which are the natural vectors of mistletoe (Frochot and Sallé 1980; Oliva and Colinas 2007; Tsopelas et al. 2004). Frugivorous birds such as thrushes are thus likely to play an important role in the population dynamics of mistletoe, but there is a lack of studies dealing with this aspect in the literature and further research is thus needed.

We also found an allometric relationship between mistletoe age, biomass, and stem diameter, indicating that mistletoe biomass increases with age and thus over time weaken infected trees. Long-term mistletoe infection can result in abnormal growth of infected branches, crown dieback, and death (Geils and Hawksworth 2002). Although we did not formally test for the effects of mistletoe infection on fir crown damage, recent works showed that mistletoe infection on pines can lead to crown degradation by reducing the surface of photosynthetic tissue (Rigling et al. 2010). But removal of infected trees may not be a suitable regulation strategy of mistletoe dynamics, as enhanced favorable light conditions in thinned stands may parallely improve habitat quality of the mistle thrush (Turdus viscivorus L.) (Noetzli et al. 2003).

Contrary to mistletoe, bark beetles are generally more abundant on crown-damaged trees that have already been weakened by biotic or abiotic factors. In this study, the vitality of trees was described by the fraction crown defoliation, which in turn affects photosynthetic area, carbohydrate reserves, and late-wood production (Kulman 1971). According to Kulman (1971), there is a minimum defoliation threshold at which radial-growth decrease becomes evident. Bark beetle abundance was also associated with tree diameter. Beetles were generally found on trees with diameters (DBH) between 12.7 and $44.5 \mathrm{~cm}$. Beetle attacks on Pinus ponderosa occur on trees larger than approximately $63.7 \mathrm{~cm}$ (Negrón et al. 2008). No relationship was found between tree social status, tree competition indices, and bark beetle abundance, indicating that bark beetles mainly attacked weakened trees independently of the tree's social status. However, trees attacked by bark beetles were not 
infected by mistletoe. This contradicts the general assumption that bark beetles may preferentially colonize trees when growth and defense mechanisms are strongly reduced by mistletoe (Lieutier et al. 2007).

In the study sites, five bark beetle species attacked $A$. $a l b a$. Their spatial distributions were heterogeneous between and within trees. P. pityographus was mainly found on dead trees, whereas $P$. spinidens and $P$. vorontzovi were much more abundant on declining trees, suggesting that the bark beetle community is influenced by the health status of silver firs, via tree defense mechanisms (Lieutier et al. 2007). In agreement with the results of Pernek et al. (2009), P. vorontzovi exploited mainly branches, while $P$. spinidens was mainly found in the bark stem samples in the upper part of the crown of declining trees. This may be a case of niche differentiation leading to lower inter-specific competition on declining trees (Lieutier et al. 2007). Pernek et al. (2009) have equally noticed that $P$. spinidens and $P$. vorontzovi, together with the bark beetle $C$. piceae (this bark beetle was found in our traps), are considered responsible for the dramatic and most recent dieback of silver fir in southern parts of Europe.

\subsection{Effects of mistletoe and bark beetles on silver fir growth}

Dobbertin and Rigling (2006) concluded for pines that mistletoe infection can be considered as both a predisposing and a contributing factor for tree death, by increasing needle loss following drought and by increasing water stress during drought, respectively. Unlike its host, $V$. album does not down-regulate its water loss even during a severe drought event. This allows the maintenance of an osmotic pressure gradient to promote tree sap flow into the parasite, except for during severe drought periods in which such a mechanism is not sufficient to prevent mistletoe decline before the decline of its host (Escher et al. 2008). In the context of climate change, $V$. album is expected to act as a bio-indicator of silver fir decline (Idžojtic et al. 2008).

We found that growth decrease occurred after mistletoe infection, especially for the periods of 2003-2007 and 2004 2007. From 2001 to 2007, the decrease in growth rate was stronger for infected trees than for uninfected ones. But two contrasting explanations are possible: (1) V. album infection led to growth decreases or (2) tree weakening promoted the infection and growth of mistletoe. Because the growth decrease became significant after 2002, which coincides with the beginning of mistletoe infections, the first hypothesis is more likely. To confirm direct effects of biotic agents on tree growth, we used a new method, never tested in previous studies. As we know in our case the date of mistletoe infection, we statistically modeled the growth dynamics of each tree using climate effect and tree ring autocorrelation during the period before infection, and we compared results from the model after infection to measured tree ring record. This method allows disentangling the climate effects from the biotic effects. When trees are infected by mistletoe, the average of simulated growth is higher than the average of measurements. This method can be successfully used to study other pathogen impacts. However, modeling had some limits because of management and mortality effects. In this study, the model was calibrated during the period (1964-1996) where thinning has not occurred. Thinning occurred certainly in 1997, so some trees showed a high variation between the simulated and the observed growth because they are located near thinning area, but interpretations remain unchanged. Consequently, mistletoe can be considered as predisposing factor for silver fir decline because mistletoe acted as a long-term factor that weakened trees (in this study, trees infected with mistletoe were not dead in 2010).

Unlike mistletoe infection, bark beetle attack was difficult to predict. However, it is known that trunk attack leads to rapid tree death (Lieutier et al. 2007), so it was assumed that individuals emerging in 2010 were the descendants of the previous year's generation (2009). Bark beetle attacks were associated with decreases in the growth rates of already weakened trees. However, dead trees tended to show greater historical growth rates than did living trees. Abgrall (2000) suggested that Picea abies (L. Karst) individuals with faster growth were more vulnerable to Ips typographus $\mathrm{L}$. because these trees mobilized more reserves for tree-ring development and less for resistance mechanisms. We found similar trends in firs of Mont-Ventoux, especially since 2003, during which time the forests in southeastern France experienced a severe drought period. During consecutive years of severe water stress, trees may become more vulnerable and attractive to bark beetles due to resulting reductions in resin production, changes in resin components, or enhanced emission of the insects' aggregation pheromones (Wermelinger et al. 2008). Bark beetle populations can then explode, and even healthy trees may be successfully attacked (Rouault et al. 2006). In this study, several healthy trees (trees with no growth decrease and no crown damage) were infested on their branches by the most abundant bark beetle species (P. pityographus and $P$. vorontzovi). This result would mean that trees attacked only on their branches were not susceptible to decline. Although past bark beetle infestations were not formally estimated before 2010 in the present study, we suggest that insect populations at Mont-Ventoux may currently be high compared to their historic levels. Bark beetle population dynamics could have been favored by some or all of the following factors: the severe drought periods in 2003 and 2004 (Cailleret and Davi 2011); high tree mortality rates, reaching $70 \%$ in some locations (Cailleret 2011); and lack of removal of dead trees by forest managers due to a constraining landscape and the assumption that dead wood promotes biodiversity. Although susceptibility of conifers may increase during a summer drought period, appropriate rainfall during the following 
winter could allow trees to recover insect resistance, thus constraining the success of attacks the following year (Lieutier et al. 2007). In 2008, the growth of infested trees was still decreasing, and actually many of the infested trees are dead. In contrast to mistletoe, bark beetles could not clearly be implicated in tree growth decrease because the history of their infestation of this forest stand was unknown. Radial growth alone was found not to be a suitable indicator of tree vulnerability to bark beetle attacks; rather, it may be useful to study the morphological traits of resin ducts (Kane and Kolb 2010).

\subsection{Factors involved in forest decline}

Early theories of forest decline invoked direct negative effects of anthropogenic factors, such as air pollution and soil acidification (Bonneau 1989; Reich 1987) on forests. Drought stress was further recognized as a key factor involved in the reduction of tree vitality (Becker 1987; Hogg et al. 2002). Currently, forest decline is considered as a result of interactions between abiotic, biotic, and anthropogenic factors (Oliva and Colinas 2007). Global change may amplify decline by increasing drought or storm events, which indirectly increase tree vulnerability to subsequent biotic factors, such as insects, phytopathogenic fungi, or viruses (Cherubini et al. 2002; Desprez-Loustau et al. 2006; Marçais and Bréda 2006; Rouault et al. 2006; Wermelinger et al. 2008). On Mont-Ventoux, forest decline was primarily triggered by climatic factors (Cailleret 2011). Abiotic factors contribute to tree weakening, but this study emphasized that biotic factors can play an important role in decline and forest mortality, as we provided evidence that both insects and plant tree parasites can negatively impact tree growth. Mistletoe may specifically contribute to tree decline processes as active predisposing and inciting factors by acting as a long-term factor that weakened trees. We had insufficient data to clearly estimate the impact of bark beetles on tree growth because stands were followed up only in 2010 and no information on stand history was available. However, it is likely that bark beetles acted as contributing factors (factors that substantially reduce the vitality of weakened trees and finally cause mortality) as they attacked trees already weakened by others abiotic factors.

\section{Conclusion}

By studying trees attacked either by bark beetles or by mistletoe but not both, we provided here evidence that both plant (mistletoe) and animal (bark beetles) tree parasites are likely to choose trees diverging in growth characteristics. Mistletoe developed primarily on isolated and dominant trees that had higher past growth rates than non-infected dominated trees. Conversely, bark beetles primarily exploited defoliated and declining trees with lower past growth rates. Further work is now needed to model tree growth patterns in interaction with local insect population dynamics to strengthen our knowledge of host-parasite interactions in a context of forest decline.

Acknowledgments We thank N. Mariotte and W. Brunetto (INRAURFM) for their contribution to field measurements, H. Picot for making traps, and A. Chalon for laboratory analysis. We also thank anonymous reviewers for their very constructive remarks on an earlier version of this paper.

Funding The project was supported by an ANR program (DRYADE, ANR-06-VULN-004) and by the Ministry of Food, Agriculture, Fisheries, Rural Affairs and Land Settlement, Department of Forest Health, France.

\section{Appendix}

Table 7 Comparison of proportions values of tree population $(N=227)$ and the sub-samples (mistletoe, $N=20$; bark beetles, $N=48$ ) between the three classes of (1) defoliation, (2) diameter, (3) slope of past growth since 2003, and (4) the distance from the crest

\begin{tabular}{lccc}
\hline $\begin{array}{l}\text { Classes } \\
\text { Defoliation }\end{array}$ & Mistletoe & Bark beetles & Whole population \\
$>10 \%$ & 0.250 & 0.386 & 0.319 \\
Intermediate & 0.550 & 0.477 & 0.538 \\
$0 \%$ & 0.200 & 0.136 & 0.144 \\
Diameter & & & \\
$<25.5 \mathrm{~cm}$ & 0.450 & 0.333 & 0.289 \\
Intermediate & 0.250 & 0.267 & 0.240 \\
$>32.0 \mathrm{~cm}$ & 0.300 & 0.400 & 0.471 \\
BAI slope & & & \\
$<-0.004$ & 0.250 & 0.400 & 0.321 \\
Intermediate & 0.450 & 0.422 & 0.454 \\
$>0.004$ & 0.300 & 0.178 & 0.225 \\
Distance from the crest & & \\
$<200 \mathrm{~m}$ & 0.400 & 0.444 & 0.370 \\
intermediate & 0.100 & 0.244 & 0.335 \\
$>400 \mathrm{~m}$ & 0.500 & 0.311 & 0.295 \\
\hline
\end{tabular}

\section{References}

Abgrall J-F. (2000) Expertise collective sur les tempêtes, la sensibilité des forêts, et sur leur reconstitution. La tornade de décembre 1999, risques sanitaires et stratégies de gestion. Cemagref, 29p. 
Aitken S, Yeaman S, Holliday JA, Wand T, Curtis-McLane S (2008) Adaptation, migration or extirpation: climate change outcomes for tree populations. Evol Appl 1:95-111

Allen CD, Macalady AK, Chenchouni H, Bachelet D, McDowell N, Vennetier M, Kitzberger T, Rigling A, Breshears DD, Hogg ET, Gonzalez P, Fensham R, Zhang Z, Castro J, Demidova N, Lim JH, Allard G, Running SW, Semerci A, Cobb N (2010) A global overview of drought and heat-induced tree mortality reveals emerging climate change risks for forests. For Ecol Manag 259:660-684

Barbu C (2009) Impact of mistletoe attack (Viscum album ssp. abietis) on the radial growth of silver fir: a case study in the North of Eastern Carpathians. Ann For Res 52:89-96

Becker M (1987) Bilan de santé actuel et rétrospectif du sapin (Abies alba Mill.) dans les Vosges. Étude écologique et dendrochronologique. Ann For Res 44:379-402

Bonneau M (1989) Que sait-on maintenant des causes du "dépérissement" des forêts ? Rev Forest Fr XLI-5:367-386

Cailleret M, Davi H (2011) Effects of climate on diameter growth of co-occurring Fagus sylvatica and Abies alba along an altitudinal gradient. Trees 25:265-276

Cailleret M. (2011) Causes fonctionnelles du dépérissement et de la mortalité du sapin pectiné en Provence. PhD thesis. University of Aix-Marseille III.

Cherubini P, Fontana G, Rigling D, Dobbertin M, Brang P, Innes JL (2002) Tree-life history prior to death: two fungal root pathogens affect tree-ring growth differently. J Ecol 90:839-850

Desprez-Loustau M-L, Marçais B, Nageleisen L-M, Piou D, Vannini A (2006) Interactive effects of drought and pathogens in forest trees. Ann For Sci 63:597-612

Dobbertin M, Rigling A (2006) Pine mistletoe (Viscum album ssp. austriacum) contributes to Scots pine (Pinus sylvestris) mortality in the Rhone valley of Switzerland. For Path 36:309-322

Escher P, Peuke AD, Bannister P, Fink S, Hartung W, Jiang F, Rennenberg $\mathrm{H}$ (2008) Transpiration, $\mathrm{CO}_{2}$ assimilation, WUE, and stomatal aperture in leaves of Viscum album (L.): effect of abscisic acid (ABA) in the xylem sap of its host (Populus $\times$ euamericana). Plant Physiol Biochem 46:64-70

Faccoli, M., Battisti, A., Masutti, L. (2005) Phenology of Tomicus destruens (Wollaston) in northern Italian pine stands. In: Lieutier F. and Ghaioule D. (eds) Entomological research in Mediterranean forest ecosystems, INRA editions, pp. 185-193.

Frochot H, Sallé G (1980) Modalités de dissémination et d'implantation du gui. Rev For Fr XXXII:505-519

Führer E (2000) Forest functions, ecosystem stability and management. Forest Ecol Manag 132:29-38

Geils B.W. and Hawksworth F.G. (2002) Damage, effects, and importance of dwarf mistletoes. In: USDA Forest Service Gen. Tech. Rep. RMRS-GTR-98, pp. 57-65.

Girard F, Vennetier M, Guibal F, Corona C, Ouarmim S, Herrero A (2012) Pinus halepensis Mill. Crown development and fruiting declined with repeated drought in Mediterranean France. Eur J For Res 131:919-931

Haack RA (2006) Exotic bark- and wood-boring Coleoptera in the United States: recent establishments and interceptions. Can J For Res 36:269-288

Harvell CD, Mitchell CE, Ward JR, Altizer S, Dobson AP, Ostfeld RS, Samuel MD (2002) Climate warming and disease risks for terrestrial and marine biota. Science 296:2158-2162

Hogg EH, Brandt JP, Kochtubajda B (2002) Growth and dieback of aspen forests in northwestern Alberta, Canada, in relation to climate and insects. Can J For Res 32:823-832

Idžojtic M, Pernar R, Glavas M, Zebec M, Diminic D (2008) The incidence of mistletoe (Viscum album ssp. abietis) on silver fir (Abies alba Mill.) in Croatia. Biologia 63:81-85
Kane JM, Kolb TE (2010) Importance of resin ducts in reducing ponderosa pine mortality from bark beetle attack. Oecologia 164:601-609

Kulman HM (1971) Effects of insect defoliation on growth and mortality of trees. Annu Rev Entomol 16:289-324

Kurz WA, Dymond CC, Stinson G, Rampley GJ, Neilson ET, Carroll AL, Ebata T, Safranyik L (2008) Mountain pine beetle and forest carbon feedback to climate change. Nature 452:987-990

Liebhold AM, MacDonald WL, Bergdahl D, Mastro VC (1995) Invasion by exotic forest pests: a threat to forest ecosystems. Forest Sci Monogr 30.

Lieutier F, Day KR, Battisti A, Grégoire J-C, Evans HF (2007) Bark and wood boring insects in living trees in Europe, a synthesis. Springer, New York.

Lindner M, Maroschek M, Netherer S, Kremer A, Barbati A, GarciaGonzalo J, Seidl R, Delzon S, Corona P, Kolström M, Lexer MJ, Marchetti M (2010) Climate change impacts, adaptive capacity, and vulnerability of European forest ecosystems. Forest Ecol Manag 259:698-709

Manetti MC, Cutini A (2006) Tree-ring growth of silver fir (Abies alba Mill.) in two stands under different silvicultural systems in central Italy. Dendrochronologia 23:145-150

Manion PD (1981) Tree disease concepts. Prentice-Hall, Englewood Cliffs

Marçais B, Bréda N (2006) Role of an opportunistic pathogen in the decline of stressed oak trees. J Ecol 94:1214-1223

Martin GL, Ek AR (1984) A comparison of competition measures and growth models for predicting plantation red pine diameter and height growth. Forest Sci 30:731-743

Mattson WJ, Haack RA (1987) The role of drought in outbreaks of plant-eating insects. BioScience 37:110-118

Negrón JF, Allen K, Cook B, Withrow JR (2008) Susceptibility of ponderosa pine, Pinus ponderosa (Dougl. ex Laws.), to mountain pine beetle, Dendroctonus ponderosae Hopkins, attack in unevenaged stands in the Black Hills of South Dakota and Wyoming USA. Forest Ecol Manag 254:327-334

Noetzli KP, Müller B, Sieber TN (2003) Impact of population dynamics of white mistletoe on European silver fir. Ann For Sci 60:773-779

Oliva J, Colinas C (2007) Decline of silver fir (Abies alba Mill.) stands in the Spanish Pyrenees: role of management, historic dynamics and pathogens. Forest Ecol Manag 252:84-97

Pernek M, Matošević D, Hrašovec B, Kučinić M, Wegensteiner R (2009) Occurrence of pathogens in outbreak populations of Pityokteines spp. (Coleoptera, Curculionidae, Scolytinae) in silver fir forests. J Pest Sci 82:343-349

Potocic N, Cosic T, Pilas I (2005) The influence of climate and soil properties on calcium nutrition and vitality of silver fir (Abies alba Mill.). Environ Pollut 137:596-602

R Development Core Team (2005) R: a language and environment for statistical computing. R Foundation for Statistical Computing, Vienna, Austria. ISBN 3-900051-07-0, URL: http://www.R-project.org).

Reich PB (1987) Quantifying plant response to ozone: a unifying theory. Tree Physiol 3:63-91

Rigling A, Eilmann B, Koechli R, Dobbertin M (2010) Mistletoeinduced crown degradation in Scots pine in a xeric environment. Tree Physiol 30:845-852

Rouault G, Candau J-N, Lieutier F, Nageleisen L-M, Martin J-C, Warzée N (2006) Effects of drought and heat on forest insect populations in relation to the 2003 drought in Western Europe. Ann For Sci 63:613-624

Sala A, Piper F, Hoch G (2010) Physiological mechanisms of droughtinduced tree mortality are far from being resolved. New Phytol 186:274-281

Scarascia-Mugnozza G, Oswald H, Piussi P, Radoglou K (2000) Forests of the Mediterranean region: gaps in knowledge and research needs. Forest Ecol Manag 132:97-109 
Tsopelas P, Angelopoulos A, Economou A, Soulioti N (2004) Mistletoe (Viscum album L.) in the fir forest of Mount Parnis, Greece. Forest Ecol Manag 202:59-65

Van Mangtem PJ, Stephenson NL, Byrne JC, Daniels LD, Franklin JF, Fulé PZ, Harmon ME, Larson AJ, Smith JM, Taylor AH, Veblen TT (2009) widespread increase of tree mortality rates in the Western United States. Science 323:521524

Wermelinger B, Rigling A, Schneider MD, Dobbertin M (2008) Assessing the role of bark- and wood-boring insects in the decline of Scots pine (Pinus sylvestris) in the Swiss Rhone valley. Ecol Entomol 33:239-249 